\title{
PENGARUH KELENGKAPAN BARANG DAN HARGA TERHADAP MINAT BELANJA DI PASAR TRADISIONAL CIBEUNYING
}

\author{
Tri Almunawaroh ${ }^{1}$, \\ Muhammad Ngasifudin ${ }^{2}$ \\ Pendidikan Ekonomi, STKIP Majenang. ${ }^{1}$. \\ Email: tri_almun@yahoo.co.id ${ }^{1}$, \\ Pendidikan Ekonomi, STKIP Majenang ${ }^{2}$ \\ Email: ngasifudinelaziz@gmail.com².
}

\begin{abstract}
Abstrak
Hasil observasi menunjukan manfaat dari pasar tradisional Cibeunying belum terlihat secara maksimal. Dikatakan demikian karena masih adanya kios yang belum terisi oleh para pedagang, selain itu juga masih banyak warga yang lebih memilih belanja di pasar induk Majenang. Pasalanya harga barang yang diperjualbelikan lebih murah dan barangnya lebih lengkap daripada di pasar Cibeunying. Walaupun demikian, masih tetap ada sebagian warga yang tetap berkunjung dan berbelanja ke pasar tradisional Cibeunying. Tujuan dari penelitian ini adalah untuk mengetahui pengaruh kelengkapan barang dan harga terhadap minat belanja masyarakat dan untuk mengetahui cara untuk meningkatkan minat belanja masyarakat di pasar Cibeunying. Metode pengumpulan datanya menggunakan observasi, wawancara dan kuesioner. Populasinya adalah konsumen pasar tradisional Cibeunying. Sampelnya, konsumen yang datang dan membeli minimal 2 kali di pasar tersebut. Teknik samplingnya menggunakan non probability sampling, yaitu accidental sampling. Data yang diperoleh dianalisis dengan mengunakan regresi linear berganda. Untuk mengetahui strategi/cara meningkatkan minat belanja masyarakat digunakan metode analisis deskriptif kualitatif. Hasil penelitian menunjukan bahwa Secara simultan variable kelengkapan barang dan harga secara bersama-sama berpengaruh sebesar 39,3\% terhadap minat belanja. Peningkatan minat belanja dapat dilakukan dengan memaksimalkn fungsi media sosial, dengan mengupdate informasi mengenai barang, harga dan promosi melalui instagram, fanspage FB, WAG, dan sebagainya.

Kata kunci: kelengkapan barang, harga, minat belanja.
\end{abstract}

\section{PENDAHULUAN}

Pasar Tradisional menurut Peraturan Menteri Perdagangan Republik Indonesia nomor 53 tahun 2008 adalah pasar yang dibangun dan dikelola oleh Pemerintah, Pemerintah Daerah (PemDa), Swasta, Badan Usaha Milik Negara (BUMN) dan Badan Usaha Milik Daerah (BUMD) termasuk kerjasama dengan swasta dengan tempat usaha berupa toko, kios, los dan tenda yang dimiliki/dikelola oleh pedagang kecil, menengah, swadaya masyarakat atau koperasi dengan usaha skala kecil, modal kecil dan dengan proses jual beli barang dagangan melalui tawar menawar. Pasar tradisional bukan sekedar sebagai tempat jual beli semata, namun lebih dari itu, pasar terkait dengan konsepsi hidup dan interaksi sosial budaya (Aliyah, 2020). Pasar tradisional memegang peran sosial dengan menyediakan kebutuhan sehari-hari. Peran ekonomi terwujud dengan mendukung aktivitas ekonomi masyarakat, menghasilkan finansial bagi pedagang dan pendapatan bagi pemerintah daerah setempat sebagai pengelola pasar. Adapun peran budaya, dari interaksi yang terjadi di pasar tradisional menciptakan hubungan antar stake holder menjadi intens, pasar bukan lagi hanya menjadi tempat belanja, tetapi juga sumber informasi dan tempat wisata.

Karena fungsi ekonomi, pasar menjadi penggerak roda perekonomian di daerah setempat. Selain itu pasar juga sebagai sumber pendapatan bagi pemerintah daerah, apalagi pada zaman sekarang pasar tradisional bukan hanya berdiri di setiap kabupaten atau kecamatan, melainkan tingkat desa. Melalui gerakan "bangga mbangun desa" yang digalakan oleh pemerintah kabupaten Cilacap, desa Cibeunying berinisiatif mendirikan pasar tradisional yang pengelolaannya dibawah BUMDes. Pasar yang belum lama dibangun oleh pemerintah desa Cibeunying ini disambut baik oleh masyarakat. Berbagai even diadakan 
untuk memeriahkan acara dalam peresmian. Pasar yang terletak ditengah desa dan dapat dikatakan cukup strategis ini ramai dikunjungi warga pada hari minggu, karena selain banyak yang berbelanja, banyak ibuibu yang mengikuti senam sehat di halaman pasar tradisional Cibeunying. Akan tetapi selama 3 tahun berjalan, manfaat dari pasar tradisional belum terlihat secara maksimal. Dikatakan demikian karena dari hasil observasi dilokasi penelitian dan wawancara dengan beberapa masyarakat sekitar, masih banyak warga yang lebih memilih belanja di pasar induk Majenang. Pasalnya harga barang yang diperjualbelikan lebih murah dan lebih lengkap daripada di pasar tradisional Cibeunying. Walaupun demikian, masih tetap ada sebagian warga yang tetap berkunjung dan berbelanja ke pasar tradisional Cibeunying. Benarkah faktor kelengkapan barang dan harga yang mempengaruhi rendahnya minat belanja masyarakat sekitar untuk berbelanja di pasar tradisional Cibeunying? Bagaimana cara/strategi untuk meningkatkan minat beli masyarakat untuk belanja di pasar tradisional Cibeuying?

Hasil penelitian sebelumnya mengatakan variabel kepercayaan berpengaruh positif dan signifikan terhadap minat beli (Shahnaz \& Wahyono, 2016), penelitian ini berjudul "Faktor yang mempengaruhi minat beli konsumen di toko online". Variable kepercayaan adalah salah satu faktor, pastinya masih ada faktor lain yang dapat mempengaruhi minat beli, factor lain tersebut diantaranya adalah variable kelengapan produk dan harga. Selain itu, konsumen toko online sangat berbeda karakteristiknya dengan konsumen pasar tradisional yang menjadi subyek dari penelitian ini.

Selain penelitian di atas, dilakukan juga penelitian tentang pengaruh variable kelengkapan produk dan penetapan harga terhadap keputusan pembelian konsumen. Hasilnya menunjukan bahwa secara parsial kelengkapan produk tidak berpengaruh terhadap keputusan pembelian sedangkan penetapan harga berpengaruh signifikan terhadap keputusan pembelian. Secara simultan kelengkapan produk dan penetapan harga berpengaruh positif dan signifikan terhadap keputusan pembelian (Lesmana \& Juwardi, 2017). Sayangnya penelitian tersebut dilakukan pada subyek yang sangat kecil, yaitu pada sebuah toko disuatu daerah, sehingga hasilnya tidak dapat digeneralisasi dan berlaku secara umum disemua tempat.

Penelitian yang ketiga dilakukan oleh Enos korowa dengan judul "pengaruh kelengkapan produk dan harga terhadap pembelian ulang konsumen (studi kasus Freshmart Bahu Manado)". Hasil penelitiannya menunjukan bahwa kelengkapan barang tidak berpengaruh positif terhadap pembelian ulang konsumen, akan tetapi harga berpengaruh positif terhadap pembelian ulang konsumen di Freshmart Bahu Manado (Korowa et al., 2018). Dengan konsumen yang berbeda karakteristiknya, hasil dapat berbeda jika dilakukan di tempat lain, walau begitu hasil penelitian ini sangat bermanfaat bagi pihak manajemen Frashmart Bahu Manado.

Selanjutnya adalah penelitian dengan judul pengaruh kelengkapan produk, kualitas layanan dan tata letak terhadap keputusan pembelian (studi kasus pada Golden Pasar Swalayan di kota Manado). Hasil penelitiannya menunjukkan bahwa baik secara parsial maupun secara simultan kelengkapan produk, kualitas layanan dan tata letak berpengaruh positif dan signifikan terhadap keputusan pembelian di Golden Pasar Swalayan di Manado. Pihak manajemen golden pasar swalayan di manado diharapkan dapat memfokuskan pada variabel kelengkapan produk, kualitas layanan dan tata letak(Ita et al., 2019). Tujuannya adalah supaya manajemen dapat memiliki informasi dan pengetahuan untuk meningkatkan keputusan pembelian konsumennya.

Setelah memaparkan beberapa penelitian tentang perilaku konsumen dan faktor yang mempengaruhinya, ternyata belum ada yang meneliti secara khusus tentang pengaruh kelengkapan produk dan harga terhadap minat belanja. Selain perbedaan obyek dan subyek penelitian, lokasi penelitian pun berbeda dengan penelitian sebelumya. Penelitian ini menjadi penting untuk mengetahui akar masalah yang menyebabkan kurang berkembangnya pasar tradisional Cibeunying yang sepi peminat. sehingga dapat menentukan strategi pemasaran yang tepat sebagai solusi untuk meningkatkan minat masyarakat untuk belanja di pasar tradisional tersebut.Tujuan dari penelitian ini adalah untuk mengetahui pengaruh kelengkapan barang dan harga terhadap minat belanja masyarakat di pasar tradisional Cibeunying. Selain itu juga untuk mengetahui cara/upaya dalam meningkatkan minat belanja masyarakat di pasar tersebut. 


\section{KAJIAN PUSTAKA DAN HIPOTESIS Kelengkapan barang}

Menurut Ma'ruf kelengkapan barang adalah proses pengadaan produk-produk yang sesuai dengan bisnis yang dijalani toko (produk berbasis makanan, pakaian, barang kebutuhan rumah, produk umum, dan lain-lain atau kombinasi) untuk di sediakan dalam toko pada jumlah, waktu, dan harga yang sesuai untuk mencapai sasaran toko atau perusahaan ritel (Ita et al., 2019). Adapun menurut philip kotler kelengkapan barang adalah tersedianya semua jenis barang yang ditawarkan untuk dimiliki, dipakai atau dikonsumsi oleh konsumen yang dihasilkan oleh suatu produsen (Lesmana \& Juwardi, 2017). Dari pengertian tersebut dapat diketahui indikator dari kelengkapan produk meliputi keragaman dan ketersediaan produk. Keragaman dilihat dari lebar, panjang dan dalamnya bauran produk. Sedangkan ketersediaan dilihat dari tersedianya barang yang akan dibeli atau dipesan.

Raharjani mengemukakan indikator kelengkapan barang meliputi tingkat keberagaman produk yang dijual, variasi produk yang dijual, tersedianya produk yang dijual, dan banyaknya macam merek yang tersedia (Lesmana \& Juwardi, 2017). Jadi Kelengkapan barang dalam fokus penelitian ini meliputi adanya berbagai macam barang kebutuhan masyarakat yang dijual di pasar tradisional Cibeunying, adanya variasi bentuk dan model dari barang-barang tersebut, tersedianya barang yang dicari oleh konsumen dalam hal ini adalah masyarakat desa Cibeunying, dan adanya berbagai macam merek barang dagang yang dijual di pasar tradisional Cibeunying.

\section{Harga}

Harga dapat diartikan sebagai jumlah uang (satuan moneter) dan/atau non-moneter yang mengandung kegunaan tertentu yang diperlukan untuk mendapatkan sebuah produk (Tjiptono \& Chandra, 2012). Indikator harga menurut Fandy Tjiptono terdiri dari tingkat harga umum, produk tertentu dan tingkat harga pesaing (Lesmana \& Juwardi, 2017). Sedikit berbeda dengan yang diungkapkan oleh Kotler dan Armstrong yang mengatakan ada empat indikator harga, yaitu: harga yang terjangkau, harga yang sesuai dengan kualitas produk, Daya saing harga, harga yang sesuai dengan manfaat produk (Korowa et al., 2018).

\section{Minat belanja}

Menurut Schiffman dan Kanuk, Minat merupakan ketertarikan seseorang terhadap suatu produk dengan mencari informasi yang lebih, untuk menambah keyakinan konsumen bahwa produk yang di inginkannya memiliki kualitas, manfaat dan keuntungan (Shahnaz \& Wahyono, 2016). Menurut Schiffman dan Kanuk indikator dari minat beli sebagai berikut (Hidayati et al., 2013):

a. Ketertarikan (interest).

b. Keinginan (desire).

c. Keyakinan (conviction).

Minat belanja dapat dipengaruhi oleh beberapa faktor, diantaranya faktor "product" (lengkap dan tidaknya produk) dan "price" (harga yang terjangkau). Dimana faktor kelengkapan harga sebagai Variabel X1 dan harga sebagai variable X2, sedangkan minat belanja sebagai variable Y. Untuk lebih jelasnya dapat dilihat pada kerangka pemikiran penelitian pada gambar 1.

Gambar 1. Kerangka Pemikiran

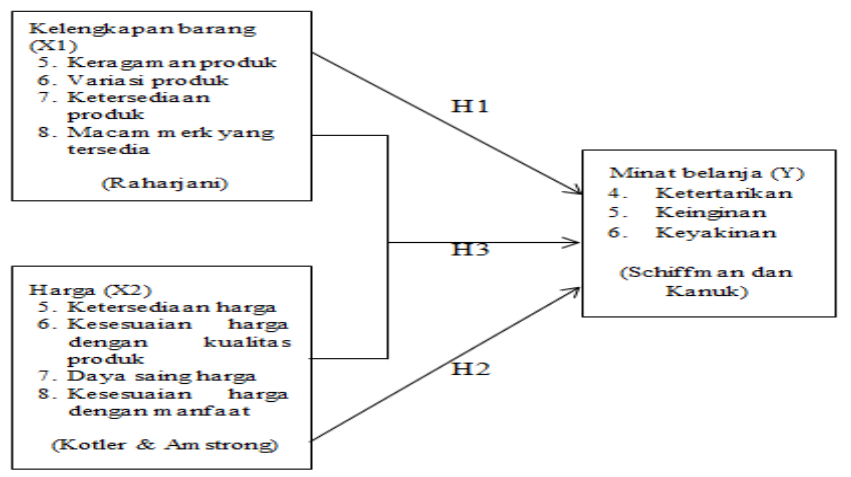




\section{HIPOTESIS}

Hipotesis dari penelitian ini adalah sebagai berikut:

H1 : Kelengkapan barang berpengaruh terhadap minat belanja masyarakat di pasar tradisional Cibeunying.

H2 : Harga berpengaruh terhadap minat belanja masyarakat di pasar tradisional Cibeunying.

H3 : Kelengkapan barang dan harga bersama-sama berpengaruh terhadap minat belanja masyarakat di pasar tradisional Cibeunying.

\section{METODE PENELITIAN}

Penelitian ini termasuk dalam penelitian lapangan (field research). Dilihat dari pendekatan analisisnya, penelitian ini termasuk penelitian gabungan (mixed research) yaitu menggabungkan penelitian kuntitatif dan kualitatif dalam meneliti satu masalah (Yusuf, 2017). Jika dilihat dari karakteristik masalah berdasarkan kategori fungsionalnya, termasuk penelitian korelasional, yaitu penelitian yang dimaksudkan untuk meneliti kemungkinan hubungan yang terjadi antarvariabel dengan memperhatikan besaran koefisien korelasi (Sanusi, 2011).

Populasi dalam penelitian ini adalah konsumen yang belanja di pasar tradisional Cibeunying. Sampel yang digunakan adalah konsumen yang minimal 2 kali datang dan membeli barang di pasar tradisional Cibeunying dengan maksud dengan pengalamannya membeli dan mengunjungi pasar tradisional Cibeunying dianggap telah memahami dan dapat membandingkan dengan pasar tradisional lain. Karena jumlah dan identitas anggota populasinya tidak diketahui secara pasti maka teknik sampling yang digunakan adalah accidental sampling, yaitu penentuann sampel dengan cara menemukan responden siapa saja yang dapat dijangkau atau ditemui (Suharsaputra, 2014) yang merupakan teknik sampling Non Probability, teknik yang tidak memberikan kesempatan yang sama bagi setiap anggota untuk dipilih menjadi sampel.

Data penelitian dalam penelitian ini dikumpulkan dengan menggunakan teknik:

a. Observasi:

Observasi digunakan di lokasi penelitian untuk mengidentifikasi permasalahan yang muncul dan untuk mengetahui keadaan real di pasar tradisional Cibeunying.

b. Wawancara

Untuk memperoleh data yang akurat tentang masalah yang terjadi di pasar tradisional Cibeunying. Wawancara dilakukan kepada ketua BUMDes yang telah mendirikan dan mengelola pasar tradisional Cibeunying, selain iu wawancara juga dilakukan kepada para pedagang yang berjualan di pasar tersebut.

c. Kuesioner/Angket:

Digunakan untuk mengumpulkan data tentang pendapat konsumen mengenai kelengkapan barang, harga dan minat belanja masyarakat di pasar tradisional Cibeunying. Kuesioner disusun mandiri dengan berpedoman pada indikator dan kisi-kisi berikut ini:

Tabel 1. Kisi-kisi Kuesioner

\begin{tabular}{|c|c|c|c|}
\hline No. & Variabel & Indikator & Butir soal \\
\hline \multirow[t]{4}{*}{1} & \multirow{4}{*}{$\begin{array}{l}\text { Kelengkapan } \\
\text { barang (X1) } \\
\text { (Raharjani) }\end{array}$} & 1. $\quad$ Keragaman produk & 1,2 \\
\hline & & 2. $\quad$ Variasi produk & 3 \\
\hline & & 3. Ketersediaan produk & 4,5 \\
\hline & & 4. Macam merk yang tersedia & 6 \\
\hline \multirow[t]{4}{*}{2.} & \multirow[t]{3}{*}{ Harga (X2) } & 1. $\quad$ Ketersediaan harga & 7 \\
\hline & & $\begin{array}{ll}\text { 2. } & \text { Kesesuaian harga dengan } \\
\text { kualitas produk }\end{array}$ & 8 \\
\hline & & 3. Daya saing harga & $9,10,11$ \\
\hline & $\begin{array}{l}\text { (Kotler \& } \\
\text { Amstrong) }\end{array}$ & $\begin{array}{l}\text { 4. Kesesuaian harga dengan } \\
\text { manfaat }\end{array}$ & 12 \\
\hline
\end{tabular}




\begin{tabular}{|l|l|c|c|}
\hline 3. & Minat belanja (Y) & $1 . \quad$ Ketertarikan & 13 \\
\cline { 3 - 4 } & \multirow{2}{*}{$\begin{array}{l}\text { (Schiffman dan } \\
\text { Kanuk) }\end{array}$} & 2. Keinginan & 14 \\
\cline { 2 - 3 } & 3. Keyakinan & 15,16 \\
\hline \multicolumn{2}{|c|}{ Jumlah } & 16 \\
\hline
\end{tabular}

Kuesioner disusun dalam bentuk angket dan disediakan lima opsi pilihan dengan teknik skala penilaian. Keseluruhan angket di susun dengan teknik self report, yaitu dengan meminta responden untuk memberikan penilaian sesuai dengan tanggapan atau kesan mereka. Alternatif pilihan yang disediakan terdiri atas, Sangat Setuju, Setuju, Ragu-ragu, Tidak Setuju, Sangat Tidak Setuju. Untuk pernyataan positif, masing-masing pilihan ini diberikan bobot penilaian 5 untuk pilihan "Sangat Setuju" (SS), 4 untuk pilihan "Setuju" (S), 3 untuk pilihan "Ragu-ragu" (R), 2 untuk pilihan "Tidak Setuju" (TS), 1 untuk pilihan "Sangat Tidak Setuju" (STS). Untuk pernyataan negative skor nilai diterapkan secara terbalik. Untuk memastikan tingkat akurasi dan konsistensi pada alat ukur, maka dilakukan pengujian validitas dan realibilitas.

Uji validitas dilakukan untuk menguji keabsahan pernyataan yang dijadikan keusioner. Dari 100 angket yang diberikan, hanya 75 responden yang memenuhi syarat sebagai sumber data. Syarat responden yang dapat dijadikan sumber data adalah konsumen yang mempunyai frekuensi tiga kali atau lebih dalam mengunjungi pasar tradisional Cibeunying. Ini disyaratkan dengan maksud orang yang sudah mengunjungi tiga kali atau lebih dapat memahami kondisi pasar yang sebenarnya. Sesuai dengan jumlah responden yang memenuhi syarat yaitu 75 orang, maka didapat bahwa t table adalah 0,235 . Hasil perhitungan uji validitas dapat dilihat pada tabel 1.

Tabel 2. Hasil Uji Validitas Data

\begin{tabular}{|c|c|c|c|}
\hline Pernyataan & r Hitung & r tabel & Keterangan \\
\hline 1 & 0,592 & 0,235 & Valid \\
\hline 2 & 0,522 & 0,235 & Valid \\
\hline 3 & 0,464 & 0,235 & Valid \\
\hline 4 & 0,462 & 0,235 & Valid \\
\hline 5 & 0,448 & 0,235 & Valid \\
\hline 6 & 0,453 & 0,235 & Valid \\
\hline 7 & 0,361 & 0,235 & Valid \\
\hline 8 & 0,427 & 0,235 & Valid \\
\hline 9 & 0,653 & 0,235 & Valid \\
\hline 10 & 0,444 & 0,235 & Valid \\
\hline 11 & 0,475 & 0,235 & Valid \\
\hline 12 & 0,269 & 0,235 & Valid \\
\hline 13 & 0,519 & 0,235 & Valid \\
\hline 14 & 0,413 & 0,235 & Valid \\
\hline 15 & 0,409 & 0,235 & Valid \\
\hline 16 & 0,462 & 0,235 & Valid \\
\hline
\end{tabular}

Dari tabel dapat diketahui hasil perhitungan validitas di peroleh $r$ hitung lebih besar dari $r$ tabel, dengan demikian dapat dikatakan pernyataan diatas adalah valid. Adapun untuk besarnya cronbach's alpha sebesar 0,837 . Jika nilai cronbach alpha yang didapatkan dari hasil perhitungan lebih besar dari 0,60 maka disimpulkan quisioner tersebur reliable/konsisten. Nilai signifikansi pada hasil uji normalitas 
Kolmogorov-smirnov adalah 0,190 artinya data tersebut berdistribusi normal karena nilai Asymp. Sig. (2tailed) lebih besar dari 0,05.

Adapun metode analisis data yang digunakan adalah:

a. Analisis regresi linear berganda

Analisis regresi linear berganda digunakan untuk mengukur pengaruh antar variabel yang memiliki lebih dari satu variabel prediktor. Oleh sebab itu, untuk mengetahui pengaruh kelengkapan produk dan harga terhadap minat belanja masyarakat desa Cibeunying digunakan metode analisis regresi linier berganda dengan data kuantitatif yang bersumber dari responden dalam bentuk angket.

b. Analisis deskriptif

Analisis deskriptif digunakan untuk menganalisis data kualitatif yang diperoleh dari observasi dan wawancara, data ini dikumpulkan untuk mengetahui strategi pemasaran / cara yang dapat meningkatkan minat beli masyarakat.

\section{HASIL DAN PEMBAHASAN}

Hasil

- Uji koefisien determinan

Nilai koefisien determinan sebesar 0,393 hal ini menunjukan bahwa variable kelengkapan barang dan harga berpengaruh terhadap minat belanja sebesar 39,3\%. Dengan demikian 60,7\% dipengaruhi oleh faktor-faktor di luar variabel kelengkapan barang dan harga. Nilai koefisien ditunjukan dalam tabel 2.

Tabel 3. Hasil Uji Koefisien Determinan

\begin{tabular}{|l|r|r|r|r|}
\multicolumn{7}{|c|}{ Model Summary } \\
\hline Model & R & R Square & $\begin{array}{c}\text { Adjusted R } \\
\text { Square }\end{array}$ & $\begin{array}{c}\text { Std. Error of the } \\
\text { Estimate }\end{array}$ \\
\hline 1 & $.627 \mathrm{~s}$ & .393 & .376 & 1.229 \\
\hline
\end{tabular}

a. Predictors: (Constant), Kelengkapan barang, Harga

- Uji regresi linear berganda

Hasil uji regresi terlihat pada persamaan $\mathrm{Y}=3,214+0,011 \mathrm{X} 1+0,531 \mathrm{X} 2$. Persamaan regresi linear berganda ini diperoleh dari tabel Coefficient

Tabel 4. Hasil Uji Regresi Berganda

\begin{tabular}{|c|c|c|c|c|c|c|}
\hline \multicolumn{7}{|c|}{ Coefficients $^{a}$} \\
\hline \multirow{2}{*}{\multicolumn{2}{|c|}{ Model }} & \multicolumn{2}{|c|}{$\begin{array}{c}\text { Unstandardized } \\
\text { Coefficients }\end{array}$} & \multirow{2}{*}{$\begin{array}{c}\text { Standardized } \\
\text { Coefficients } \\
\text { Beta }\end{array}$} & \multirow[t]{2}{*}{$t$} & \multirow[t]{2}{*}{ Sig. } \\
\hline & & B & Std. Error & & & \\
\hline \multirow{3}{*}{1} & (Constant) & 3.214 & 1.732 & & 1.856 & .068 \\
\hline & $\begin{array}{l}\text { Kelengkapan } \\
\text { barang }\end{array}$ & .011 & .058 & .022 & .189 & .851 \\
\hline & Harga & .531 & .098 & .614 & 5.391 & .000 \\
\hline
\end{tabular}

a. Dependent Variable: Minat belanja

Nilai konstanta sebesar 3,214 artinya minat belanja masyarakat desa Cibeunying akan tetap atau konstan jika tanpa pengaruh yang ditimbulkan dari variable kelengkapan barang dan harga. Nilai koefisien regresi variabel kelengkapan barang sebesar 0,011. Nilai koefisien regresi positif tersebut berarti 
terdapat pengaruh positif dari variabel kelengkapan barang terhadap minat belanja, atau semakin lengkap barang yang tersedia di pasar tradisional Cibeunying maka minat belanja masyarakat semakin tinggi. Setiap 1\% kenaikan tingkat kelengkapan barang akan menaikan 0,011 minat belanja masyarakat.

Nilai koefisien regresi variabel harga sebesar 0,531. Nilai koefisien regresi positif tersebut berarti terdapat pengaruh positif dari variabel harga terhadap minat belanja, atau semakin harga murah maka minat belanja masyarakat di pasar tradisional Cibeunying semakin tinggi, sebaliknya semakin malah harga yang ditawarkan makan minat belanja semakin rendah. Setiap penerapan strategi promosi harga (potongan harga, harga lebih murah, lebih bersaing, dll) dengan perubahan 1\% menjadi lebih baik maka akan terjadi penambahan minat belanja sebesar 0,531.

- Uji hipotesis

a. Uji t (parsial)

Berdasarkan hasil pengolahan data menggunakan SPSS diketahui bahwa nilai t hitung kelengkapan barang sebesar 0,189, sedangkan nilai t table dengan df $73-1=72$ dengan nilai derajat signifikansi 0,05 adalah sebesar 1,666. Dengan demikian nilai t hitung $>\mathrm{t}$ table sehingga hipotesi alternative kedua H1 diterima yaitu kelengkapan barang berpengaruh positif terhadap minat belanja masyarakat di pasar tradisional Cibeunying.

Nilai t hitung variabel harga sebesar 5,391, dengan t tabel 1,666. Sehingga nilai t hitung $>\mathrm{t}$ tabel, artinya hipotesisi diterima, variable harga berpengaruh positif terhadap minat belanja masyarakat di pasar tradisional Cibeunying.

Tabel 5. Hasil Uji Parsial

Coefficients $^{a}$

\begin{tabular}{|c|c|c|c|c|c|c|}
\hline \multirow{2}{*}{\multicolumn{2}{|c|}{ Model }} & \multicolumn{2}{|c|}{ Unstandardized Coefficients } & \multirow{2}{*}{$\begin{array}{c}\text { Standardized } \\
\text { Coefficients } \\
\text { Beta }\end{array}$} & \multirow[t]{2}{*}{$\mathrm{t}$} & \multirow[t]{2}{*}{ Sig. } \\
\hline & & $\mathrm{B}$ & Std. Error & & & \\
\hline \multirow{3}{*}{1} & (Constant) & 3.214 & 1.732 & & 1.856 & .068 \\
\hline & Kelengkapan barang & .011 & .058 & .022 & .189 & .851 \\
\hline & Harga & .531 & .098 & .614 & 5.391 & .000 \\
\hline
\end{tabular}

a. Dependent Variable: Minat belanja

b. Uji F (simultan)

Dari persamaan regresi $\mathrm{Y}=3,214+0,011 \mathrm{X} 1+0,531 \mathrm{X} 2$ diperoleh $\mathrm{F}$ hitung 22,963 (sig.0,000), dengan df = 2,72 maka diperoleh $F$ tabel 3,12 maka disimpulkan bahwa $F$ hitung $>\mathrm{F}$ tabel. Dengan demikian ada kontribusi positif yang dihasilkan oleh variable kelengkapan barang dan harga terhadap minat belanja masyarakat di pasar tradisional Cibeunying.

Tabel 6. Hasil Uji Simultan

ANOVA $^{\mathrm{a}}$

\begin{tabular}{|c|c|c|c|c|c|c|}
\hline \multicolumn{2}{|c|}{ Model } & Sum of Squares & $d f$ & Mean Square & $\mathrm{F}$ & Sig. \\
\hline \multirow{3}{*}{1} & Regression & 69.342 & 2 & 34.671 & 22.963 & $.000^{\mathrm{b}}$ \\
\hline & Residual & 107.198 & 71 & 1.510 & & \\
\hline & Total & 176.541 & 73 & & & \\
\hline
\end{tabular}

a. Dependent Variable: Minat Belanja

b. Predictors: (Constant), Kelengkapan barang, harga 


\section{PEMBAHASAN}

Observasi awal menemukan hal yang menjadi permasalahan bagi pelaku pasar yaitu rendahnya minat belanja masyarakat sekitar untuk berbelanja ke pasar Cibeunying. Salah satu penyebabnya adalah adanya rumor tentang kurang lengkapnya barang yang dijual dan harganya yang mahal. Rumor tersebut berasal dari sebagian orang yang pernah datang beberapa kali ke pasar dimasa awal peresmian pasar Cibeunying. Kesan pertama yang kurang baik membuat sebagian mereka mencurahkan perasaannya kepada orang lain. Sehingga tersebarlah berita yang semakin lama menjadi keyakinan dan membuat banyak orang lebih memilih ke pasar lain walaupun letaknya lebih jauh.

Hal tersebut dapat terjadi karena keadaan pasar saat awal pembukaan belum sebaik keadaan sekarang. Seiring berjalannya waktu, evaluasi dan perbaikan manajemen membuat pasar Cibeunying semakin berkembang. Adapun situasinya dapat digambarkan dalam penjelasan berikut:

1. Kurang lengkapnya barang yang dijual disebabkan oleh sedikitnya pedagang yang berjualan di pasar tersebut. Pada tahun awal pembukaan pasar hanya sedikit kios yang terisi oleh pedagang. Harga sewa kios yang lumayan tinggi membuat orang keberatan untuk ikut berpartisipasi dalam meramaikan pasar, karena tidak semua orang mempunyai modal yang banyak saat memulai bisnis. Setelah diadakan evaluasi dengan memberikan pengurangan harga sewa kios, jumlah pedagang bertambah sehingga mengurangi jumlah kios yang kosong. Dengan begitu barang yang dijual semakin beragam dan bervariasi.

2. Harga yang mahal dan kurang bersaing pada awal pembukaan pasar disebabkan oleh harga sewa kios yang cukup tinggi bagi sebuah pasar yang baru saja dibuka. Harga jual dibentuk berdasarkan pada besarnya biaya operasional yang dikeluarkan pedagang. Sewa kios yang mahal membuat biaya operasional tinggi dan mengakibatkan harga jual barang ikut menyesuaikan. Setelah dilakukan evaluasi, harga sewa kios diturunkan dari 2,5 juta/tahun menjadi 1,25 juta/tahun (untuk harga kios yang terletak di depan atau dekat jalan). Adapun kios yang terletak di belakang dipatok dengan harga 1 juta/tahun dari harga awal yang tadinya 2 juta rupiah. Bukan hanya menurunkan sewa kios, pengelola pasar bahkan mengijinkan para pedagang membayarnya dengan cara mengangsur setiap bulan, hal ini bertujuan untuk meringankan pedagang dalam membayar sewa kios. Kebijakan tersebut diambil untuk membantu para pedagang yang masih belum stabil pendapatnnya karena masih sedikitnya konsumen yang berkunjung. Dengan mengurangi biaya operasional diharapkan pedagang dapat menurunkan harga barang yang dijualnya sehingga dapat bersaing dengan pedagang di tempat lain.

Pasar tradisional Cibeunying didirikan pada tahun 2017 dengan 40 kios dan 40 los, Sehingga total tempat yang disewakan kepada pedagang ada 80 tempat. Hingga bulan Agustus 2020 tercatat 28 kios dan 10 los yang terisi. Jumlah tersebut menunjukan banyaknya jumlah pedagang yang berjualan di pasar tradisional Cibeunying. Dan jumlah pedagang menunjukan banyak sedikitnya barang yang dijual di pasar tersebut. Karena masih minimnya pedagang yang berjualan, maka ketersediaan dan variasi barang yang dijualpun kurang beragam. Hal tersebut yang membuat konsumen tidak memiliki banyak alternative pilihan saat berbelanja di pasar Cibeunying. Konsumen dari pasar tersebut cukup beragam, ada pria dan wanita, remaja dan dewasa, dari yang berpendidikan SD, SMP, SMA sampai dengan sarjana. Namun sebagian besar didominasi oleh wanita berusia antara 21-40 tahun dan pendidikan SD dengan pendapatan kurang dari Rp 500.000,- /bulan.

Dilihat dari karakteristik respondennya sangat beragam tingkat pendidikan dan usianya, tentu hal tersebut mempengaruhi pola pikir dalam menafsirkan dan menginterpretasikan makna kelengkapan barang dan harga yang murah. Ternyata tidak semua konsumen beranggapan bahwa tingkat kelengkapan barang rendah dan harga kurang bersaing. Sebagian responden ada yang mengatakan bahwa barang yang dijual di pasar Cibeunying sudah lengkap dan lumayan murah. Setelah ditanya makna lengkap yang dimaksud, mereka mengatakan "lengkap" untuk kebutuhan sehari-hari dalam kategori makanan, dari sembako, sayur mayur, makanan ringan, makanan mentah dan makanan matang (siap makan). Pola pikir sederhana ini dimiliki oleh masyarakat yang berusia diatas 50 tahun dan mempunyai tingkat pendidikan SD dan SMP. 
Adapun sebagian masyarakat lain sudah banyak yang memahami makna kelengkapan barang tidak hanya meliputi bahan makanan saja, tetapi meliputi semua kebutuhan hidup manusia. Selain itu mereka juga mampu memahami makna lengkap dari segi variasi model, type dan merk barang. Seperti yang dikemukakan oleh Raharjani bahwa indikator kelengkapan barang meliputi tingkat keragaman produk yang dijual, variasi produk yang dijual, tersedianya produk yang dijual (Lesmana \& Juwardi, 2017), dan tersedianya berbagai macam merek produk. Keragaman maksudnya adalah barang yang dijual beraneka macam, dari bahan sembako, makanan kering, makanan basah, peralatan dapur, perkakas, tekstil, sepatu, tas, dan kebutuhan lainnya. Adapun variasi produk dapat digambarkan dengan berbagai jenis variasi barang yang dijual, misalnya dari jenis cabai ada cabai merah, cabai hijau, cabai rawit, dan lainnya. Ketersediaan barang maksudnya adalah ketika konsumen mencari sesuatu yang dibutuhkan selalu ada di pasar tersebut. Dan terakhir ada berbagai macam merek barang. Misalnya ketika pedagang menjual susu kental manis, di kios tersebut menyediakan susu dengan merek Indomilk, Frisian Flag, dan sebagainya.

Bukan hanya makna dari kelengkapan barang saja yang berbeda penafsiran antar konsumen. Harga juga memiliki persepsi yang berbeda. Ini disebabkan oleh tingkat ekonomi masing-masing individu (tingkat pendapatan). Bagi masyarakat yang memiliki pendapatan tinggi selisih seribu dengan tempat lain masih dikatakan murah, tetapi bagi sebagian masyarakat dapat dikatakan mahal (mereka berfikir murah hanya jika harganya lebih rendah dari harga ditempat lain). Faktanya tidak semua barang yang dijual di pasar Cibeunying mahal, dan tidak semuanya memiliki harga murah. Semua barang sangat bervarias. Misalnya barang A memiliki harga yang lebih rendah dari tempat lain, tetapi barang B sedikit lebih tinggi dibandingkan dengan pasar tradisional lain. Jadi sangat wajar dan harga masih dapat dikatakan dapat bersaing.

Setiap konsumen memiliki penafsiran yang berbeda-beda tentang lengkapnya barang sesuai dengan usia, pengetahuan dan tingkat pendidikan. Karena itu secara parsial kelengkapan barang mempunyai pengaruh yang lebih kecil terhadap minat belanja, dibandingkan dengan variable harga. Bahkan dalam penelitian yang dilakukan oleh Rosa Lesmana variable kelengkapan barang secara parsial tidak berpengaruh sama sekali pada keputusan pembelian. Artinya penelitian ini mendukung dan menguatkan hasil penelitian sebelumnya. Jika kelengkapan barang berpengaruh sedikit terhadap minat belanja, maka wajar jika tidak berpengaruh sama sekali kepada keputusan pembelian. Dengan demikian konsumen memiliki minat dan akhirnya memutuskan untuk membeli suatu barang bukan karena lengkap atau tidaknya barang tersebut, bisa jadi barang yang dicari tersedia tetapi tidak sesuai dengan harga yang diinginkan. Karena harga berpengaruh besar terhadap minat belanja dan kemudian memutuskan untuk membelinya. Dari hasil penelitian ini dengan yang dilakukan oleh Rosa Lesmana memiliki hasil yang sama dan saling mendukung. Sehingga bukan barangnya yang dilengkapi semua jenis dan variasinya, tetapi sediakan barang yang dibutuhkan oleh konsumen, barang-barang yang banyak dicari dan barangbarang yang biasanya digunakan oleh masyarakat setempat selaku target konsumen.

Walaupun terbukti mempunyai pengaruh terhadap minat belanja, kelengkapan produk dan harga bukan satu-satunya faktor yang mempengaruhi. Karena itu promosi selalu gencar dilakukan oleh pihak pengelola pasar. Promosi ini dilakukan untuk memberitahu masyarakat luas akan keadaan pasar yang sebenarnya, sehingga masyarakat tidak lagi enggan berkunjung karena mendengar rumor yang beredar. Walau bagaimanapun persepsi lengkap dan murah bisa berbeda dari satu orang dengan yang lainnya, sehingga sangat perlu mendorong masyarakat untuk mengunjungi sehingga dapat menilai sendiri, bukan hanya percaya dan ikut dengan penilaian orang lain. Bisa saja menurut satu orang mahal tetapi menurut orang lain murah. Yang jelas harga barang yang dijual di pasar Cibeunying sama atau memiliki selisih sedikit dengan pasar-pasar disekitarnya. Artinya harga barang yang dijual dapat bersaing.

Adapun program promosi yang sudah pernah dijalanakan oleh BUMDes sebagai pengelola pasar adalah mengadakan istighasah al-Asma'ul Husna bersama masyarakat desa Cibeunying, mengadakan gerak jalan yang diikuti oleh semua sekolah dan instansi yang ada di wilayah Cibeunying, start dan finish karnaval dalam rangka HUT RI yang sebelumnya selalu dilakukan di balai desa Cibeunying, dan pembagian kupon belanja kepada konsumen pasar yang telah berbelanja mencapai nominal tertentu. 
Walau bagaimanapun, rumor beredar karena kurangnya informasi yang didapatkan masyarakat seputar barang dan harga yang dijual di pasar Cibeunying. Dalam hal menyampaikan informasi seputar pasar dan kegiatannya alangkah baiknya jika ditunjang dengan media masa kini yang lebih relevan dengan perkembangan zaman, misalnya dapat dilakukan dengan membuat fanspage di media sosial facebook, atau membuat Whatsap group, yang beranggotakan para pedagang dan warga masyarakat desa Cibeunying sebagai target konsumen, sehingga masyarakat dapat memantau perubahan harga barang, memberi informasi tentang barang yang tersedia, mensosialisasikan program-program yang dilakukan oleh pengelola pasar, atau mempromosikan apa saja yang berkaitan dengan pasar.

Selain untuk menyampaikan pesan atau informasi terkait pasar, promosi melalui media sosial juga dapat membangun dan memperkokoh hubungan antara konsumen (pelanggan) dengan pedagang, sehingga hubungan mereka bukan lagi seorang penjual dan pembeli saja, tetapi mitra yang saling membutuhkan dan saling membantu. seperti yang dijelaskan dalam penelitian Shahnas \& Wahyono bahwa kepercayaan berpengaruh positif dan signifkan terhadap minat belanja. Biasanya masyarakat akan berbelanja ketempat yang sama jika sudah mengenal penjualnya, bukan karena harga ditempat tersebut paling murah, tetapi karena ada kepercayaan dan ada hubungan yang terjalin diantara mereka sehingga membuat dirinya menjadi pelanggan tetap. Menjalin hubungan untuk menaruh kepercayaan kepada konsumen untuk menjadi pelanggan tidaklah mudah, perlu komunikasi yang intens dan kontinue, tidak harus bertemu langsung, karena itu media sosial sangat tepat untuk membangun komunikasi dengan pelanggan. Semakin tinggi kepercayaan konsumen terhadap penjual (pedagang) maka semakin tinggi pula minat belanja konsumen ditempat tersebut, sebaliknya semakin kecil tingkat kepercayaan konsumen terhadap penjual maka semakin kecil minat mereka untuk berbelanja ((Shahnaz \& Wahyono, 2016)

Selain penyampaian informasi yang berbasis digital, pemesanan juga dapat dilakukan secara online melalui fanspage dan WAG yang sudah dibuat, dengan memanfaatkan ojek online sebagai jasa pengantar barangnya. Karena tidak sedikit masyarakat jaman sekarang yang menginginkan kemudahan akses dalam mendapatkan barang. Sehingga pangsa pasar bukan hanya menyasar pada ibu-ibu paruh baya yang berlokasi dekat dengan pasar saja, tetapi juga ibu-ibu muda dan remaja milenial.

Selain product, price dan promotion, Satu hal lagi yang menjadi perhatian peneliti, yaitu place. Fasilitas pasar juga mempunyai kemungkinan untuk mempengaruhi minat masyarakat untuk berkunjung dan berbelanja, karena kenyamanan dalam belanja sudah menjadi prioritas masyarakat jaman sekarang, sehingga dipandang sangat perlu bagi pengelola desa untuk memperbaiki fasiltas dan menjaga kebersihan pasar. Secara umum semua pelaku pasar (baik pengelola pasar, pedagang maupun konsumen) mempunyai kewajiban bersama dalam menjaga kebersihan, tetapi sangat diperlukan adanya petugas khusus yang bertugas mengkoordinir dan memastikan sampah di tong sampah telah terbuang pada TPA atau telah diangkut oleh mobil sampah. Sehingga tidak ada lagi sampah yang berserakan karena di acak-acak hewan-hewan yang berkeliaran di sekitar pasar seperti kucing dan ayam.

Selain masalah sampah, fasilitas lain yang butuh perhatian adalah kebersihan toilet dan tempat ibadah, sehingga masyarakat yang mayoritas beragama muslim dapat tenang ketika melakukan transaksi ekonomi di pasar. Jangan sampai urusan dunia melalaikan urusan akhirat warga. Tempat ibadah yang bersih membuat nyaman dalam beribadah, dan ibadah yang tenang membuat orang lebih khusyu'. Kemudian kekhusyu'an dalam berdoa akan berimabas pada kelancaran rezeki dan usaha mereka. Bukan hanya ikhtiyar yang menjadi tuntutan, tetapi juga butuh do'a untuk mewujudkan sebuah usaha.

\section{KESIMPULAN}

Hasil penelitian menunjukan bahwa variabel kelengkapan barang dan harga berpengaruh terhadap minat belanja baik secara parsial maupun secara simultan. Persepsi tentang makna kelengkapan barang dan harga tidak sama antara satu konsumen dengan konsumen lainnya, sehingga menimbulkan opini publik yang belum tentu benar di tengah masyarakat. Selain itu informasi tentang macam barang yang dijual dan harga kurang tersampaikan kepada masyarakat sehingga tidak dapat membantah opini public yang tersebar. hal tersebut menjadi salah satu alasan mengapa minat belanja di pasar Cibeunying rendah. Atas permasalahn tersebut, diharapkan pengelola pasar dapat meningkatkan kegiatan promosinya. Memaksimalkan pemanfaatan media sosial seperti instagram, fanspage, WAG dan sebagainya sebagai 
alat promosi dapat dijadikan alternative penyampaian pesan kepada masyarakat. Pedagang dapat mengupdate informasi tentang barang yang siap jual dan harga yang berlaku saat itu.

Penelitian sederhana ini tentunya masih memiliki banyak kekurangan, perlu dilakukan penelitian lanjutan untuk melengkapi hasil penelitian ini, sehingga dapat bermanfaat bagi manajemen pengelolaan pasar Cibeunying. Diharapkan pada penelitian selanjutnya dapat meneliti tentang pemanfaatan media sosial atau penerapan digital marketing sebagai upaya peningkatan minat belanja, dan perubahan tingkat penghasilan para pedagang di pasar Cibeunying setelah diterapkannya media promosi menggunakan digital marketing. Dengan begitu dapat diketahui tingkat keberhasilan dari solusi yang disajikan dalam penelitian ini.

\section{Ucapan Terimakasih}

Kami ucapkan terimakasih kepada KEMENRISTEKDIKTI atas dana hibah yang diberikan dalam menunjang berjalannya penelitian ini sehingga dapat terlaksana dengan lancar. Kami menyadari masih terdapat banyak kekurangan dalam penelitian ini, karena itu kami selalu mengharapkan kritik dan saran yang membangun demi penelitian yang lebih baik lagi.

\section{REFERENSI}

Aliyah, I. (2020). Pasar Tradisional: Kebertahanan Pasar Dalam Konstelasi Kota (M. Iqbal (ed.)). Yayasan Kita Menulis.

Hidayati, T. A., Suharyono, \& Fanani, D. (2013). Pengaruh Citra Merek Terhadap Minat Beli dan Keputusan Pembelian Konsumen. Jurnal Administrasi Bisnis (JAB), 2(1), 1-116. file:///C:/Users/L E N O V O/Downloads/85-5316-1-PB (2).pdf

Ita, M., Moniharapon, S., \& Ogi, I. W. . (2019). Pengaruh Kelengkapan Produk, Kualitas Layanan Dantata Letak Terhadap Keputusan Pembelian (Studi Kasus Pada Golden Pasar Swalayan Di Kota Manado). Jurnal EMBA: Jurnal Riset Ekonomi, Manajemen, Bisnis Dan Akuntansi, 7(1), 411-420. https://doi.org/10.35794/emba.v7i1.22382

Korowa, E., Sumayku, S., \& Asaloei, S. (2018). Pengaruh Kelengkapan Produk dan Harga terhadap Pembelian Ulang Konsumen. Jurnal Administrasi Bisnis, 6(3), 27-34.

Lesmana, R., \& Juwardi. (2017). Pengaruh Kelengkapan Produk Dan Penetapan Harga Terhadap Keputusan Pembelian Konsumen. Jurnal Pemasaran Kompetitif, 1(1), 1-19.

Sanusi, A. (2011). Metodologi Penelitian Bisnis. Salemba Empat.

Shahnaz, N. B. F., \& Wahyono. (2016). Faktor Yang Mempengaruhi Minat Beli Konsumen Di Toko Online. Management Analysis Journal, 389-399.

Suharsaputra, U. (2014). Metode Penelitian: Kuantitatif, Kualitatif, dan Tindakan. Refika Aditama. Tjiptono, F., \& Chandra, G. (2012). Pemasaran Strategik (2nd ed.). Andi.

Yusuf, M. (2017). Metode Penelitian: Kuantitatif, Kualitatif \& Penelitian Gabungan (1st ed.). Fajar Interpratama Mandiri. 